\title{
Book Review: On the Commodity Trail: The Journey of a Bargain Store Product from East to West
}

[LS blogs.Ise.ac.uk/Isereviewofbooks/2015/05/27/book-review-on-the-commodity-trail-the-journey-of-a-bargainstore-product-from-east-to-west-by-alison-hulme/

Inspired by Walter Benjamin's Arcades Project, On the Commodity Trail explores the colourful and fascinating histories of everyday objects. Susan Marie Martin finds the author's writing style, which includes historical ironies, and parallels between concepts and lived experience, have created a text accessible to a broad, curious readership.

On the Commodity Trail: The Journey of a Bargain Store Product from East to West. Alison Hulme. Bloomsbury. February 2015.

'Euro shop', 'pound shop', 'dollar store'. The name varies but the premise is the same: commodities sold at low prices. For many the relationship with the 'bargain' shop is fraught by love and loathing. Loathing is prompted by the cheap nonessentials, and the thought of the sweatshop labour that produced them. Love comes from the pursuit of a bargain, and the smug feeling that we have not been exploited.

In boom times discounters seem reserved for the terminally cheap, or those whom prosperity has overlooked. But what of their place in an era of austerity? Historically, according to Alison Hulme, times of decline were not like the present: saving back then meant not spending. However, she tells us on the first page of On the Commodity Trail, this current 'age of austerity' is not like its predecessors. Now cheap and plentiful helps maintain levels of consumption seen during the boom, and cements individual mantras of "consumption is good". For the businesses involved this means "chasing growth through smaller and smaller profits".

If our age is "characterized by the desire for immediate gratification, disposability, the fragmentation of old systems

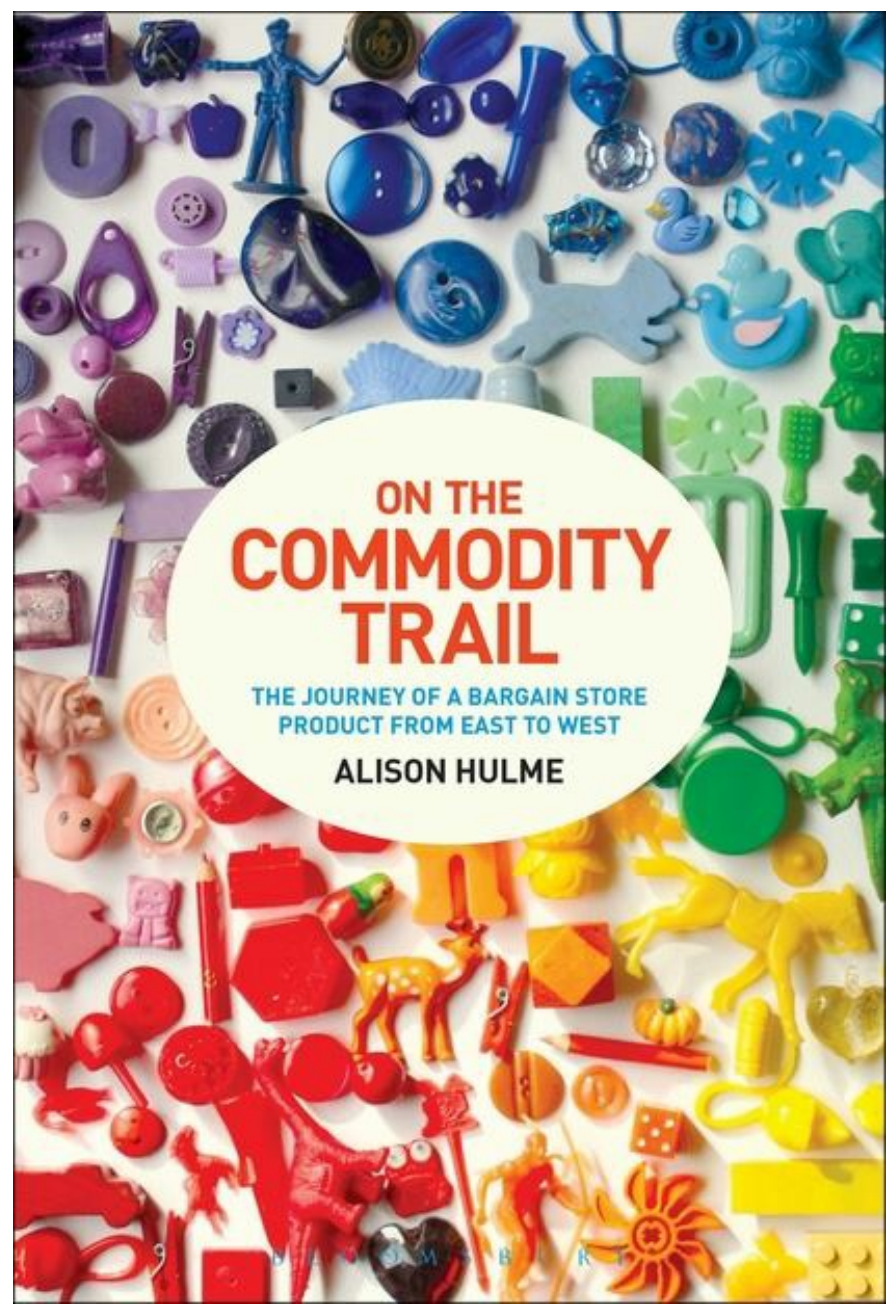
and the rise of China" then, she asserts, the commodity chain of bargain store products "is a classic trail of our times". Hulme subsequently takes the reader on a journey across the life cycle of eight bargain store commodities: a pet gravestone, a pregnancy test, a garden gnome, a plastic bonsai, a model Buddha, plastic flowers, a Chinoiserie vase, and a ship-in-a-bottle. Hulme's inspiration was the early twentieth century work of the German philosopher and cultural critic, Walter Benjamin, and his Arcades Project. However, unlike Benjamin's focus on the "bijou objects of bourgeois Paris", she opted to create an 'Arcades Project' of the pound shop.

The journey of the eight commodities is signposted by four locales: the dump, the 'commodity city', the container port, and the bargain store. The real end of the journey, is elusive: from a dump in the West, discarded commodities depart for China to begin the journey anew. That's right, the journey of curios and stocking stuffers not only ends at the dump, it begins there too. Here, impoverished rubbish pedlars seek out raw materials for the manufacturers of 
curios and stocking stuffers. Clearly, then, exploitation begins well before China's factory floor, or the sales floor in the West populated with its own cheap labour.

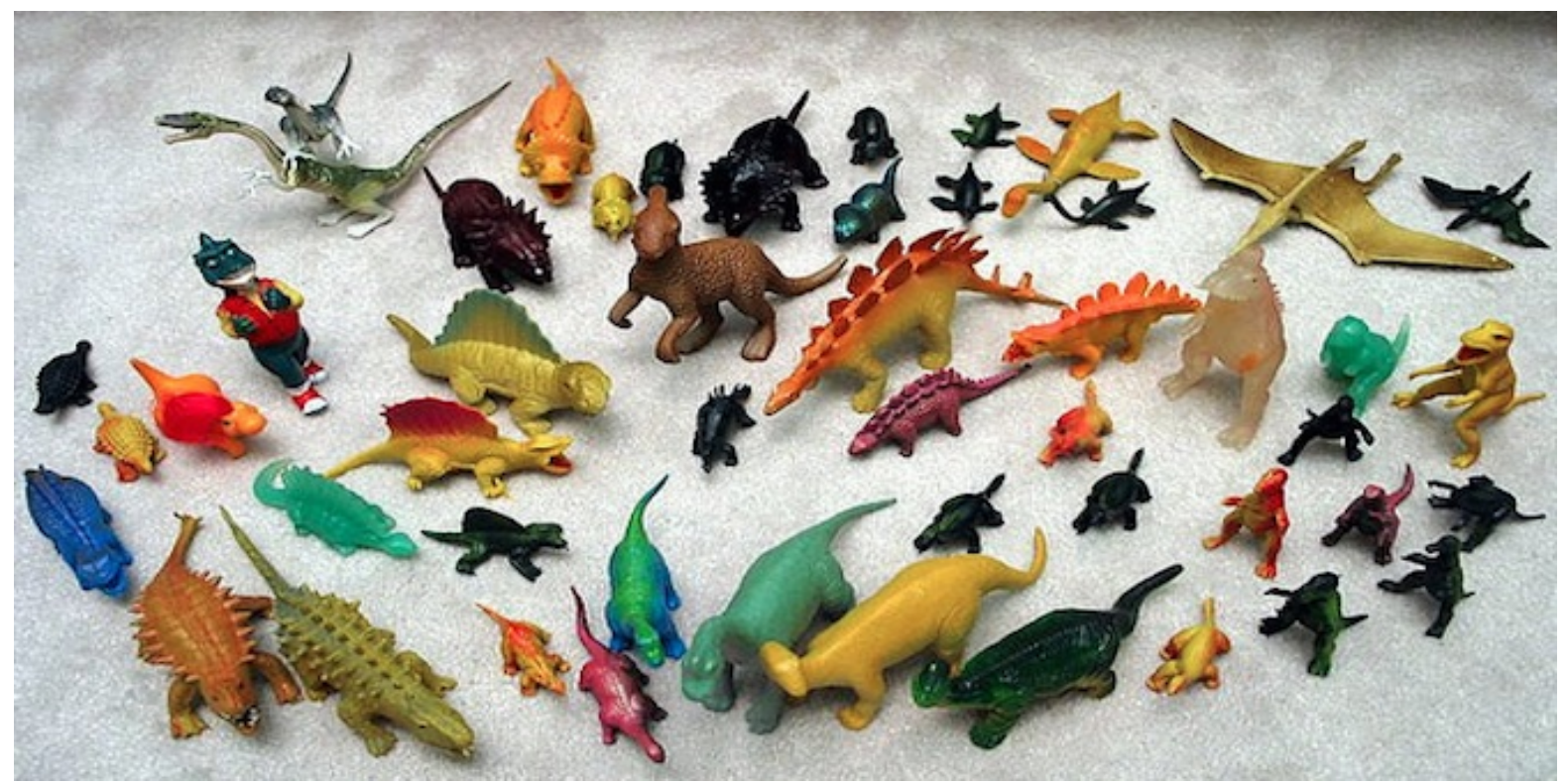

\section{Photo Credit: Denise Chan. CC-BY-SA.}

The "Commodity City" Yiwu, a place that did not exist as a city until the late 1980s, is her next stop. This manufacturing hub is anchored by what Hulme refers to as "the logic of the bargain", or "quantity and cheapness". It also epitomises China's 'Wenzhous model' of economic organization. Banned under Mao, the model is signified by four characteristics: "numerous small-scale private enterprises", "specialisation in wholesale petty commodity markets", "tens of thousands of mobile traders" facilitating the "flow of materials", and "it is made possible by various forms of non-governmental financial arrangements". Just as castoffs are transformed into new commodities that are equally disposable, Hulme's depiction of Yiwu highlights the transitoriness of the transaction, the trend, and life itself: in addition to the multitude of mobile traders, Hulme shadows a few of the many buyers who come to Yiwu on behalf of the bargain stores of the West.

The temporality of the commodity city is captured, in large part, in the way the West's obsession with copyright and, vicariously, branding, is ignored here. Hulme explores this phenomenon, and learns that in this commodity chain the very "existence" of many small participants producing small units for small profits "must fall to the many". Thus, regulatory protections such as copyright mean that profits from protected designs "fall to the few, the few grow large and the majority must fall off". This raises questions of what, exactly, Western capitalism is protecting with its emphasis on 'intellectual property rights', and answers about how it is that 'Chinese capitalism' flourishes under what has become of communism in the twenty-first century.

After the factory and the container port, the commodities and Hulme then move on to the "West's Spaces of 'Cheap'" - bargain shops in South-East London. Here she provides a thorough exploration of what she earlier designated the new age of austerity, the current one in which conspicuous consumption flourishes. The slick, orderly chain bargain stores are contrasted with the chaos and clutter of smaller, independent bargain stores. Hulme's ethnography extends to explore the theory behind instant gratification, supplemented by interviews with shoppers willing to share the ethos behind their patronage of 'cheap'.

For some it is the bargain, pure and simple, but for others it is 'honesty' and the absence of bourgeois hype. Interestingly, many revisit the 'shame' that was once heaped upon the bearer of a bag that bore the pound shop logo. During the boom and glitter of the 1980s, they claim, bargain hunting was characterised as "shameful and 
grasping". Now, Hulme asserts, a "pervasive bargain culture", underpinned by notions of democracy as the freedom to buy, and consumerism as the patriotic support of the economy, combine to transform that old stigma. The reader also meets the purchasers of the commodities to learn more about the life and purpose of, say, a plastic bonsai in their homes.

In this sense, Hulme has created a thorough and intriguing ethnography: a wealth of interviews gathered at each location on the journey are weighed against a broad base of theory. Considering the potential snobbery that could subtly infuse a study of this sort, Hulme is to be commended for the respect, objectivity, and passion she brings to the various conversations across the journey. Furthermore, her writing style, one that includes historical ironies, and parallels between concepts and lived experience, have created a text accessible to a broad, curious readership.

Susan Marie Martin holds a PhD in Applied Social Studies (Interdisciplinary) from University College Cork (National University of Ireland). Her research focuses on the impact of modernity and gentrification on the urban poor, particularly women who eke out subsistence earnings as street traders. She is an international educator, currently dividing her time between Ireland and the Middle East. Her thoughts on tangible and abstract markets, and the urban poor may be followed on Twitter @smariem13. Read more reviews by Susan.

- Copyright 2013 LSE Review of Books 